\title{
Carbonation of borehole seals: Comparing evidence from short-term laboratory experiments and long-term natural analogues
}

\author{
Christopher A. Rochelle* and Antoni E. Milodowski
}

British Geological Survey, Environmental Science Centre, Nicker Hill, Keyworth, Nottingham, NG12 5GG, UK

* Corresponding author: caro@bgs.ac.uk, tel +44 115 9363259, fax +44 115363200

\begin{abstract}
It is crucial that the engineered seals of boreholes in the vicinity of a deep storage facility remain effective for considerable timescales if the long-term geological containment of stored $\mathrm{CO}_{2}$ is to be effective. These timescales extend beyond those achievable by laboratory experiments or industrial experience. Study of the carbonation of natural Ca silicate hydrate $(\mathrm{CSH})$ phases provides a useful insight into the alteration processes and evolution of cement phases over long-timescales more comparable with those considered in performance assessments. Samples from two such natural analogues in Northern Ireland have been compared with samples from laboratory experiments on the carbonation of Portland cement. Samples showed similar carbonation reaction processes even though the natural and experimental samples underwent carbonation under very different conditions and timescales. These included conversion of the $\mathrm{CSH}$ phases to $\mathrm{CaCO}_{3}$ and $\mathrm{SiO}_{2}$, and the formation of a well-defined reaction front. In laboratory experiments the reaction front is associated with localised Ca migration, localised matrix porosity increase, and localised shrinkage of the cement matrix with concomitant cracking. Behind the reaction front is a zone of $\mathrm{CaCO}_{3}$ precipitation that partly seals porosity. A broader and more porous/permeable reaction zone was created in the laboratory experiments compared to the natural samples, and it is possible that short-term experiments might not fully replicate slower, longer-term processes. That the natural samples had only undergone limited carbonation, even though they had been exposed to atmospheric $\mathrm{CO}_{2}$ or dissolved $\mathrm{HCO}_{3}{ }^{-}$in groundwater for several thousands of years, may indicate that the limited amounts of carbonate mineral formation may have protected the CSH phases from further reaction.
\end{abstract}

\section{Introduction}

Acceptable performance of the geological storage of $\mathrm{CO}_{2}$ will need to be demonstrated in order to satisfy operational, regulatory and public acceptance criteria, and a key element of this will be the effectiveness of the seals preventing $\mathrm{CO}_{2}$ migration. At a generic level, the occurrence of natural $\mathrm{CO}_{2}$ accumulations demonstrates the containment potential of caprock materials that have not been penetrated by human activity over time periods measurable in $10^{4}-10^{6}$ a (e.g. natural $\mathrm{CO}_{2}$ fields in the USA, Pearce et al., 1996; Petzet, 1997, and China, Dai et al., 1996). Indeed, natural accumulations of $\mathrm{CO}_{2}$ show that reactions over longer timescales do not necessarily lead to wholesale dissolution and breakdown of the overlying aquicludes (i.e. if the seal was not effective the $\mathrm{CO}_{2}$ would have escaped long ago). It is however, less easy to demonstrate the long-term containment properties of the engineered (man-made) seals that will be required to prevent $\mathrm{CO}_{2}$ leakage through $\mathrm{CO}_{2}$ injection, investigation and monitoring boreholes, and other 'legacy' exploration and production wells (in the case of utilisation of depleted hydrocarbon fields), and this is an area of concern (e.g. IEA, 2005; LeNeveu, 2008; Zhang and Bachu, 2011). The efficacy and integrity of these seals is vital for long-term containment, as deterioration of the engineered seals around boreholes may provide short-circuit routes for $\mathrm{CO}_{2}$ migration and leakage regardless of the quality of the caprock seal. Key reasons that limit the demonstration of effective long-term sealing are that 'modern' Portland-type cements (upon which most oil-field cements are based) have only been in use for about 200 a (Hewlett, 1998), and that the operational design life of a typical oil well 
does not usually exceed 25-30 a. Both of these fall short of the thousand years or more timescale over which borehole seals will need to remain effective.

Laboratory experiments can provide much useful, well-constrained information on the carbonation reactions of Portland cements. The majority of studies utilise relatively static systems with small samples of cement immersed in $\mathrm{CO}_{2}$ ( \pm trace impurities) or $\mathrm{CO}_{2}$-saturated water (e.g. Jacquemet et al., 2005; Kutchko et al., 2007, 2008). In such systems carbonation reactions are driven by diffusion of $\mathrm{CO}_{2}$ (or aqueous $\mathrm{C}$ species equilibrated with $\mathrm{CO}_{2}$ ) into the cement. Typically these systems might simulate conditions at the base of the well cement, where diffusion into the bulk cement matrix occurs. A smaller number of studies have considered cement reactivity within dynamic systems, where a flow of $\mathrm{CO}_{2}$ or $\mathrm{CO}_{2}$-rich water is pumped through a sample of cement (e.g. Carey et al., 2010). Typically these systems might simulate conditions along imperfectlysealed cement/steel or cement/rock interfaces. Unfortunately, one limitation of laboratory experiments is their relatively short duration, which typically varies between days to a few months. Observations of material recovered from $\mathrm{CO}_{2}$-rich borehole environments extends this timescale up to a few decades (e.g. Carey et al., 2007), but even this falls short of performance assessment timescales for $\mathrm{CO}_{2}$ storage boreholes.

One way to address the shortage of long-timescale data is to consider naturally-occurring phases which are comparable to those found in Portland cement, and that have undergone carbonation over thousands of years - timescales comparable to those required for $\mathrm{CO}_{2}$ containment. These typically involve $\mathrm{Ca}$ silicate and $\mathrm{CSH}$ phases that have interacted with atmospheric or soil $\mathrm{CO}_{2}$, or with dissolved $\mathrm{HCO}_{3}{ }^{-}$in groundwater, for many thousands of years. Whilst it is recognised that the carbonation reactions have occurred under conditions of very different pressure, temperature and $\mathrm{CO}_{2} /$ carbonate abundance compared to those of underground $\mathrm{CO}_{2}$ storage, it is suggested that there are many similarities in the reaction processes involved. As such, it is considered that the natural carbonation of certain minerals can provide 'natural analogues' to aid understanding of the potential long-term reactivity, stability and alteration behaviour of similar phases in borehole cements.

In this paper cement carbonation reactions from laboratory experiments and natural systems are compared. The aim is to show some of the similarities in carbonation reaction between natural samples and those formed during laboratory experiments, and also to suggest reasons why they may appear different in a few aspects. It is thought that these natural analogues can extend considerably the timescales over which carbonation data are available, and provide information relevant to assessments of the future long-term performance of borehole cements.

\section{Borehole sealing and carbonation reactions}

In general terms, a completed deep well comprises three principal components: (i) the steel casing; (ii) a cement grout used to fill the gap between the steel casing and the surrounding rock; and (iii) a cement plug sealing inside the well. The behaviour and the integrity of the seal provided by these components in the subsurface are of critical importance to the long-term geological storage of $\mathrm{CO}_{2}$.

Reactions between borehole infrastructure and $\mathrm{CO}_{2}$ are recognised as potential risk factors for the long-term security of storage (e.g. IEA, 2005; IPCC, 2005; Carey et al., 2007; Rochelle et al., 2007; Kutchko et al., 2007, 2008; LeNeveu, 2008; Wigand et al., 2009; Crow et al., 2010; Zhang and Bachu, 2011). Carbonation of Portland-type cements used in well completions is thermodynamically favourable and so is going to occur if $\mathrm{CO}_{2}$ is present. In general terms, reactions between the hydrated (and residual non-hydrated) Portland cement components and $\mathrm{CO}_{2}$ produce 
carbonate minerals and dissolved ions that can leach from the cement matrix, potentially changing porosity, permeability and compressive strength. Furthermore, cement degradation causes loss of casing protection, loss of cement-casing and cement-formation bonding, resulting in leakage along interfaces between the well components and loss of zone isolation that in time could result in infrastructure failure to retain $\mathrm{CO}_{2}$.

Recent work has already reviewed cement carbonation issues in some detail (e.g. Zhang and Bachu, 2011), and only a summary of key issues in noted here. The rate and extent of cement carbonation will depend on a range of factors including; temperature, $\mathrm{CO}_{2}$ pressure, cement composition, porewater composition and fluid flow rate. The latter is of particular importance: very low flow rates will limit reactions to slow, diffusion-controlled processes; whereas very high flow rates (e.g. a leaky borehole seal) will lead to rapid carbonation by acidic, $\mathrm{CO}_{2}$-rich waters, possibly followed by the leaching of material from already carbonated cement. However, the leaching of the carbonated cement would be significantly reduced if the $\mathrm{CO}_{2}$-rich waters were already saturated with $\mathrm{CaCO}_{3}$ (e.g. having equilibrated with a host formation containing calcite).

Volumetrically the most important phases in Portland cement are portlandite $\left(\mathrm{Ca}(\mathrm{OH})_{2}\right), \mathrm{CSH}$, $\mathrm{Ca}$ aluminate hydrate $(\mathrm{CAH})$ and $\mathrm{Ca}$ sulfoaluminate hydrate phases. These (and a variety of other cement minerals) will undergo carbonation reactions, producing one of the polymorphs of $\mathrm{CaCO}_{3}$ (calcite, aragonite or vaterite) depending on the degree of supersaturation:

$\mathrm{Ca}(\mathrm{OH})_{2}+\mathrm{CO}_{2} \quad \Rightarrow \quad \mathrm{CaCO}_{3}+\mathrm{H}_{2} \mathrm{O}$

portlandite

The carbonation of $\mathrm{CSH}$ is potentially complex. It may continually dissociate $\mathrm{Ca}$, which reacts with $\mathrm{CO}_{2}$, in a cascade of reactions that progressively remove $\mathrm{Ca}$ and water from $\mathrm{CSH}$ gel, via a sequence of $\mathrm{CSH}$ phases with progressively lower Ca:Si ratio (equation [2]), with the ultimate products being $\mathrm{CaCO}_{3}(\mathrm{~s})$ and $\mathrm{SiO}_{2}$ gel (or possibly more stable silica phases over very long timescales) (equation [3]):

$2 \mathrm{Ca}_{9} \mathrm{H}_{2} \mathrm{Si}_{6} \mathrm{O}_{18}(\mathrm{OH})_{8} \cdot 6 \mathrm{H}_{2} \mathrm{O}+8 \mathrm{CO}_{2} \Rightarrow 2 \mathrm{Ca}_{5} \mathrm{Si}_{6} \mathrm{O}_{16}(\mathrm{OH})_{2} \cdot 9.5 \mathrm{H}_{2} \mathrm{O}+8 \mathrm{CaCO}_{3}+4.5 \mathrm{H}_{2} \mathrm{O}$

[2]

jennite / $\mathrm{CSH}(2)$ gel tobermorite

$\mathrm{Ca}_{5} \mathrm{Si}_{6} \mathrm{O}_{16}(\mathrm{OH})_{2} \cdot 9.5 \mathrm{H}_{2} \mathrm{O}+5 \mathrm{CO}_{2} \Rightarrow 5 \mathrm{CaCO}_{3}+6 \mathrm{SiO}_{2}+10.5 \mathrm{H}_{2} \mathrm{O}$

tobermorite / CSH(1) gel

silica gel

Alternatively, the $\mathrm{CSH}$ may react with $\mathrm{CO}_{2}$ directly to $\mathrm{CaCO}_{3}(\mathrm{~s})$ and $\mathrm{SiO}_{2}$ without forming intermediate $\mathrm{CSH}$ phases of progressively lower $\mathrm{Ca}: \mathrm{Si}$ :

$\mathrm{Ca}_{9} \mathrm{H}_{2} \mathrm{Si}_{6} \mathrm{O}_{18}(\mathrm{OH})_{8} .6 \mathrm{H}_{2} \mathrm{O}+9 \mathrm{CO}_{2} \Rightarrow 9 \mathrm{CaCO}_{3}+6 \mathrm{SiO}_{2}+11 \mathrm{H}_{2} \mathrm{O}$

jennite / $\mathrm{CSH}(2)$ gel

$\mathrm{CAH}$ appear to be even more susceptible to carbonation reaction than $\mathrm{CSH}$ phases, the reactions products are normally $\mathrm{CaCO}_{3}$ (including calcite, aragonite and vaterite) and alumina gel, which can change with time to crystalline gibbsite $\left[\mathrm{Al}(\mathrm{OH})_{3}\right]$ (Hewlett, 1998). In the case of Ca ferrites, Fe oxide gels are also formed as reaction products during carbonation. As with $\mathrm{CSH}$, the carbonation reactions of $\mathrm{CAH}$ are complex. Initial carbonation can involve the rapid formation of Ca monocarboaluminate hydrate $\left[\mathrm{Ca}_{4}\left[(\mathrm{Al}, \mathrm{Fe})(\mathrm{OH})_{6}\right]_{2} \mathrm{CO}_{3} \cdot 5 \mathrm{H}_{2} \mathrm{O}\right]$. Ultimately, this intermediate reaction product can react further with $\mathrm{CO}_{2}$ to produce $\mathrm{CaCO}_{3}$, alumina gel and gibbsite.

Any unhydrated cement clinker components (e.g. residual anhydrous Ca silicate, tricalcium aluminate and $\mathrm{Ca}$ ferrite phases) can also react directly with $\mathrm{CO}_{2}$ to form $\mathrm{CaCO}_{3}$, silica and alumina and Fe oxide gels. 
With $\mathrm{CO}_{2}$ ingress into the cement, these carbonation reactions can produce one or more reaction fronts that progressively move through the cement. Associated with these reactions are large changes in mineralogy, porewater chemistry, and porosity/permeability. Carbonation also increases the bulk density of the cement, and the resulting carbonation products may even reduce overall porosity/permeability. Critically, carbonated cement can retain its mechanical properties or even increase its strength. However, this assumes that leaching of $\mathrm{CaCO}_{3}$ from the carbonated cement does not occur. Thus pathways that allow passage of water undersaturated with respect to $\mathrm{CaCO}_{3}$ through or around the cement would adversely affect cement properties (such as cracked cement, or poor bonding of the cement with the borehole liner or the surrounding rock). It is vital, therefore, that the well cementing operation be of high quality, and that subsequent operational procedures do not damage the cement seal (Carey et al., 2007; Bachu and Bennion, 2009).

\section{Sample analysis and methods}

Samples of natural material and reacted cement plugs from the laboratory experiments were petrographically and mineralogically characterised using a variety of techniques. The reacted external surfaces and fractured interfaces between cement and steel were examined and digitally photographed using an Olympus SZX10 binocular stereomicroscope. They were then sub-sampled for more detailed petrographical characterisation and X-ray diffraction (XRD) analysis.

Samples of experimentally-reacted cement and natural altered hydrated larnite nodules were prepared as polished thin sections and polished blocks for observation by optical petrographic microscope and for high-resolution scanning electron microscope (SEM) studies. Samples were impregnated with epoxy-resin under vacuum in order to stabilise them for polished section preparation. A blue dye was added to the epoxy-resin to differentiate between porosity originally present within the vacuum-dried sample and artefacts of the sectioning process (e.g. grain plucking). The resin-impregnated samples were cut and polished under ethanol to prevent reaction of water-sensitive cement phases.

The polished thin sections were initially examined using a Zeiss Axioplan II optical petrographical photomicroscope equipped with a dedicated high-resolution digital camera, prior to SEM observation. Backscattered scanning electron microscopy (BSEM) analyses were carried out using a LEO 435VP variable pressure digital SEM fitted with a KE Developments 4-diode solidstate backscattered electron detector. The SEM instrument was also equipped with an Oxford Instruments INCA Energy 450 energy-dispersive X-ray microanalysis (EDXA) system with a thin window Si-Li X-ray detector. Polished thin sections were coated with a thin layer of carbon (approximately $250 \AA$ thick) before being examined in detail by BSEM. Samples were imaged by BSEM using a 10-20 kV electron beam accelerating potential, beam currents between 200-800 pA, and a working distance of 17-20 mm, as required. Phase identification during BSEM was aided by semi-quantitative EDXA microchemical data recorded from features of interest.

Bulk mineralogical compositions of both experimentally reacted cement plugs and naturally hydrated and carbonated Ca silicate materials were determined by XRD analysis. This was carried out using a PANalytical X'Pert Pro series diffractometer equipped with a Co-target tube, $\mathrm{X}^{\prime}$ Celerator detector and operated at $45 \mathrm{kV}$ and $40 \mathrm{~mA}$. The samples were scanned from 4.5 to $85^{\circ} 2 \theta$ at $2.76^{\circ} 2 \theta / \mathrm{min}$. Diffraction data were initially analysed using PANalytical X'Pert Highscore Plus Version 2.2a software coupled to the latest version of the International Centre for Diffraction Data (ICDD) database. Following identification of the mineral species present in the samples, mineral quantification was achieved using the Rietveld refinement technique (e.g. Snyder and Bish, 1989) using PANalytical Highscore Plus software. Where discrete alteration banding or zoning 
could be seen in the cut surfaces of samples, each distinct band was sub-sampled for XRD analysis to provide information on the mineralogy of that specific band. Sub-samples of the discrete bands were carefully taken from a cut surface using a small hand-held diamond saw mini-tool, and or prised away with a small chisel.

Aqueous samples were extracted whilst the experiments were still at run temperature and pressure. This was undertaken via a high-pressure valve and dip tube, the latter reaching to the base of the reaction vessel. Sampling involved carefully bleeding off and depressurising the aqueous sample into a plastic syringe. At the end of the experiment as much aqueous sample was removed as possible to minimise the potential for carbonate mineral precipitation on the cement sample during the slow depressurisation step needed to prevent hydrofracturing the cement.

The depressurised and degassed aqueous samples were split into several sub-samples prior to subsequent analysis. These included:

- Approximately $1 \mathrm{~mL}$ for immediate analysis of $\mathrm{pH}$. This was performed on cooled and depressurised samples using an Orion ${ }^{\circledR} 900 \mathrm{~A}$ pH meter calibrated using Whatman ${ }^{\circledR}$ NBS traceable buffers of $\mathrm{pH} \mathrm{4,} 7$ and 10 .

- $\quad 2-4 \mathrm{~mL}$ for immediate analysis of $\mathrm{CO}_{3}{ }^{2-} / \mathrm{HCO}_{3}{ }^{-}$by titration against a known amount of $\mathrm{H}_{2} \mathrm{SO}_{4}$.

- $\quad 10-12 \mathrm{~mL}$ was filtered using a $0.2 \mu \mathrm{m}$ 'Anotop' ${ }^{\circledR}$ nylon syringe filter; $8 \mathrm{~mL}$ of this was then placed into a polystyrene tube and acidified with $1-5 \% \mathrm{v} / \mathrm{v}$ (i.e. in the order of $0.08 \mathrm{~mL}$ ) of concentrated 'ARISTAR' ${ }^{\circledR} \mathrm{HNO}_{3}$ to preserve the sample. This was analysed subsequently for major and minor cations by inductively coupled plasma - optical emission spectroscopy (ICPOES).

- A further aliquot of the filtered sample (in the order of 1-2 mL) was taken and placed in a polyethylene tube for analysis of anions by ion chromatography (IC). This sample was diluted to $20-50 \%$ concentration to minimise the potential for carbonate mineral precipitation prior to analysis.

Once preserved, the latter two sample splits were stored in a fridge (at about $5{ }^{\circ} \mathrm{C}$ ) prior to analysis.

\section{Laboratory experimental studies of cement carbonation}

If the underground storage of $\mathrm{CO}_{2}$ is widely adopted, there will be many storage reservoirs in a variety of different formations lying at a range of depths, and hence having a range of in situ pressures and temperatures. Even at this current time when $\mathrm{CO}_{2}$ storage is in its infancy, it is clear that in situ conditions could easily range from about $30^{\circ} \mathrm{C}$ and 80 bar pressure (near critical conditions) to $130{ }^{\circ} \mathrm{C}$ or more and pressures of 300 bar or greater. Borehole completions will have to tolerate the presence of $\mathrm{CO}_{2}$ over this wide range of conditions, be it as a high-density supercritical phase or dissolved in formation water. Also, in the unlikely event that $\mathrm{CO}_{2}$ were to migrate out of the reservoir and rise towards the surface, it may also become a lower density gaseous phase as pressures and temperatures drop. It is important, therefore, to identify cement carbonation reactions and processes that are common to all these conditions and to many cement formulations, but also to recognise that there may be reactions and processes that are specific to one storage site or one type of cement.

Results are reported from a limited number of experiments conducted under pressures and temperatures that represent the less extreme of conditions that might be encountered during actual storage operations. These might typically be found within relatively shallow aquifers beneath the bed of the North Sea that might be more attractive in the early days of underground $\mathrm{CO}_{2}$ storage (e.g. such as at the Sleipner Gas Field, Norwegian Sector of the North Sea). 
A series of relatively simple 'batch' experiments were conducted for 110 days at $30{ }^{\circ} \mathrm{C}$ and 8 $\mathrm{MPa}(80 \mathrm{bar})$, conditions close to the critical point of $\mathrm{CO}_{2}\left(31.1^{\circ} \mathrm{C}, 7.38 \mathrm{MPa}(73.8 \mathrm{bar})\right)$. In order to provide relevance to a current $\mathrm{CO}_{2}$ storage operation, a cement formulation and steel borehole liner similar to those used at Sleipner were used (Table 1), and the seawater-salinity aqueous fluid was also representative of those at Sleipner (Table 2). Further details about the experiments are reported by Rochelle et al. (2009).

\subsection{Experimental details}

The experiments were designed to react cement/steel composite blocks with either dry $\mathrm{CO}_{2}$ or $\mathrm{CO}_{2}$-saturated porewater. An equivalent control experiment pressurised by non-reactive $\mathrm{N}_{2}$ was performed to provide a reference against which the degree of alteration caused solely by the presence of $\mathrm{CO}_{2}$ could be assessed. A summary of experimental details is given in Table 3.

The composite cement/steel blocks contained pieces of Cr-rich steel borehole casing similar to that used in well completions in the Sleipner Gas Field (acquired from Statoil). This steel was cut using a hacksaw into small, slightly curved pieces for use in the experiments (each approximately $25 \mathrm{~mm}$ long, $25 \mathrm{~mm}$ wide and $12 \mathrm{~mm}$ thick). The four cut surfaces were polished to remove surface oxidation products. The original inner and outer (curved) manufactured surfaces of the casing were kept unpolished to reflect the nature of the surface likely to be contacted by the cement in a real emplacement scenario. All surfaces were washed in acetone prior to being used in order to remove any grease or cutting fluid residue. The only surface to receive any other treatment was part of the original external surface of the casing. Half of this surface was smeared with a layer of bentonite paste approximately $2 \mathrm{~mm}$ thick. This paste was made from 1 part (by weight) of dry bentonite to 4 parts of de-ionised water, which were mixed together by hand in a small beaker. The paste was applied to act as a simplified representation of 'mudcake', and hence allow investigation of an imperfect seal due to the presence of mudcake between the steel liner and cement.

The samples of borehole cement were mixed and cured at BGS using ingredients supplied by BJ Services (Table 1). As each ingredient was added to the water, the mixture was stirred for about $30 \mathrm{~s}$ with a 'plaster whisk' running at approximately 340 revolutions $/ \mathrm{min}$. Once all the ingredients had been added, the mixture was then thoroughly mixed for about $10 \mathrm{~min}$ to ensure a homogeneous composition.

Puck-shaped composite samples of cement and steel were produced by using small polystyrene pots in the centre of which sat a piece of borehole steel. Sufficient slurry was added to almost cover the piece of steel. These partly-filled pots were then placed into small autoclaves and were pressurised to $80 \mathrm{bar}(8 \mathrm{MPa})$ with $\mathrm{Ar}$, and left to cure at $30^{\circ} \mathrm{C}$ for 28 days. Once cured, the samples were carefully extracted from the autoclaves and then from their plastic formers. The small puck-shaped composite samples were used 'as extracted' in the experiments.

A synthetic porewater representative of that found within the Utsira Formation was used in the experiments (Table 2) and was similar to that used in previous studies (Rochelle et al., 2006).

The experiments utilised a stainless steel pressure vessel holding a PTFE liner (Fig. 1). Into this liner was placed a composite cement/steel sample that was held off the bottom of the vessel by small PTFE supports. A quantity of saline water was added to immerse the solid sample, together with a small PTFE-coated stirrer bead to ensure regular mixing of the solution (stirring was typically for $2 \mathrm{~min}$ every $4 \mathrm{~h}$ ). Once assembled, the pressure vessel was placed into a thermostatically-controlled incubator accurate to better than $\pm 0.5^{\circ} \mathrm{C}$, and raised to the required pressure. A PEEK ${ }^{\mathrm{TM}}$ (polyether-ether-ketone) 'sample tube' with filter ran to the bottom of the aqueous fluid so that fluid samples could be taken whilst the experiment remained at pressure and 
temperature. On completion of the experiments the aqueous fluid was carefully extracted from the pressure vessels, sampled and preserved. The remaining solids were then carefully depressurised and sectioned prior to analysis (further details of the sampling procedures can be found in Rochelle et al., 2009).

\subsection{Summary of reactions}

Prior to detailed (destructive) analytical tests, the reacted and intact cement samples were weighed and had their dimensions measured. The presence of significant amounts of either dissolved or free phase $\mathrm{CO}_{2}$ initiated carbonation reactions of cement minerals, and uptake of $\mathrm{CO}_{2}$ into the cement. This led to increases in the weight of the (carbonated) cement samples by up to nearly $11 \%$ (Table 3 ). This was far in excess of any weight gain due to continued slow hydration of the cement (just over $2 \%$ in the $\mathrm{N}_{2}$-pressurised experiments). In terms of the degree of carbonation, free phase $\mathrm{CO}_{2}$ was only slightly more effective than dissolved $\mathrm{CO}_{2}$. Upon reaction the samples did not change their overall size, and thus carbonation increased their density. Therefore, in terms of macroscopic, bulk solids volume changes, there was no indication that carbonation would lead to large amounts of swelling or shrinkage. What is less clear from these bulk measurements, is whether the cement carbonation changed the porosity/permeability characteristics of the samples on a microscopic scale, and this is discussed below.

\subsubsection{Changes in mineralogy}

The presence of $\mathrm{CO}_{2}$ initiated significant carbonation reactions on, and within, the cement samples. Visual observations of cement from $\mathrm{CO}_{2}$-rich experiments revealed that the outer portions of the sample had been altered markedly. Typically this represented about $60-70 \%$ of the cement. Along the inner edge of this altered cement was an apparent reaction front, with what appeared to be relatively unaltered cement in the centre of the sample. Observations were similar for experiments with free $\mathrm{CO}_{2}$ and with $\mathrm{CO}_{2}$-saturated porewater. The cement completely changed appearance within the outermost zone, from a relatively homogenous grey matrix to a buff-coloured material consisting of many very fine concentric bands around an apparently unaltered residual cement core (Fig. 2a and 2b). In some areas the presence of the bentonite paste hindered the formation of a good cement-steel bond. This allowed $\mathrm{CO}_{2}$ ingress, and cement carbonation occurred adjacent to the surface of the steel in a similar way to the exterior surface of the sample (Fig. $2 \mathrm{~b}$ ). The depth of the most obviously altered zone varied across the sample, but was typically 5-8 mm. This is somewhat thicker than the $<1 \mathrm{~mm}$ altered zone observed by Kutchko et al. (2008) for comparable static tests at $50{ }^{\circ} \mathrm{C}, 300$ bar and 1 a duration. The differences in degree of carbonation may reflect the classes of cement used, (Class G cement in this study, versus Class $\mathrm{H}$ in the Kutchko et al., 2008, study), or microstructural variations caused by the different curing temperatures (e.g. Kutchko et al., 2007).

A summary of mineralogical changes is presented in Table 4. Carbonate mineral precipitates such as acicular or rosette aggregates of calcite, aragonite or vaterite coated the outside of the cement-steel composite samples as well as within them (Fig. 3a). In addition, siderite was also observed to coat the steel surface along the interface close to the exposed surface of the steel. The buff-coloured, reacted outer region of the cement was also extensively replaced by secondary calcite and vaterite, which were shown by XRD to comprise over $90 \%$ of the crystalline material. This extensive secondary $\mathrm{CaCO}_{3}$ formation would appear to reflect a reaction mechanism of primary (cement) mineral dissolution, followed by secondary mineral precipitation. These reactions 
were also relatively rapid, with complete carbonation of the cement, to a depth of up to $10 \mathrm{~mm}$ and of between $60 \%$ and $70 \%$ of the total cement volume, occurring within 110 days.

The original unreacted hydrated cement comprised mainly 'nanoparticulate' amorphous CSH and CAH hydrogels (undetected by XRD but observed petrographically by BSEM-EDXA), and fine grained crystalline portlandite and ettringite $\left[\mathrm{Ca}_{6} \mathrm{Al}_{2}\left(\mathrm{SO}_{4}\right)_{3}(\mathrm{OH})_{12} \cdot 25 \mathrm{H}_{2} \mathrm{O}\right]$, with significant residual amounts of the primary unhydrated cement clinker minerals hatrurite $\left[\mathrm{Ca}_{3} \mathrm{SiO}_{5}\right]$, larnite $\left[\beta-\mathrm{Ca}_{2} \mathrm{SiO}_{4}\right]$ and brownmillerite $\left[\mathrm{Ca}_{2}(\mathrm{Al}, \mathrm{Fe})_{2} \mathrm{O}_{5}\right]$ (Table 4$)$. The primary clinker minerals occurred as relict grains surrounded by rims of hydrated $\mathrm{CSH}$ and $\mathrm{CAH}$ hydrogel and ettringite. In the buff-coloured outer reaction zone, where carbonation was very extensive, reactions involved the complete breakdown of all of the original hydrated cement phases portlandite, $\mathrm{CSH}$ and $\mathrm{CAH}$ hydrogels, and ettringite, to form secondary $\mathrm{Ca}$ carbonates and silica gel. Residual non-hydrated clinker phases such as larnite, hatrurite and brownmillerite also had reacted extensively with the $\mathrm{CO}_{2}$, producing non-hydrated $\mathrm{Ca}$ silicocarbonate phases such as spurrite $\left[\mathrm{Ca}_{5}\left(\mathrm{SiO}_{4}\right)_{2} \mathrm{CO}_{3}\right]$ and disseminated very fine grained Fe oxide or oxyhydroxide. Discrete Al-rich breakdown products could not be discriminated in this study.

Although there was much replacement of portlandite and $\mathrm{CSH}$ phases by $\mathrm{CaCO}_{3}$ within the samples, some outermost portions of the cement plugs showed noticeable dissolution - primarily as a result of $\mathrm{Ca}$ leaching to the surrounding solution (Fig. 3b). The Ca could have been lost by direct reaction of the $\mathrm{CSH}$ phases, or through dissolution of initially-formed $\mathrm{CaCO}_{3}$ by the slightly acidic $\mathrm{CO}_{2}$-rich solution. The preferential loss of $\mathrm{Ca}$ led to a consequent increase in relative abundance of $\mathrm{Si}$ in these areas. Calcite, vaterite and some aragonite were identified as reaction products in the outer, altered parts of the cement samples. Comparable observations were made by Kutchko et al. (2007) in experiments using Class $\mathrm{H}$ well cement, although that study only identified $\mathrm{Ca}(\mathrm{OH})_{2}$ carbonation (as opposed to both $\mathrm{Ca}(\mathrm{OH})_{2}$ and $\mathrm{CSH}$ phase carbonation) and only found calcite as a $\mathrm{CaCO}_{3}$ reaction product.

In the present study a spatial relationship was observed between the $\mathrm{CaCO}_{3}$ polymorphs. In the outer, most extensively carbonated parts of the cement calcite and vaterite occur in approximately equal amounts, with subordinate aragonite. In contrast, vaterite is dominant with relatively minor calcite in the less reacted residual core of the cement, where aragonite is also more abundant. All three polymorphs of $\mathrm{CaCO}_{3}$ have also been observed in previous experimental studies (e.g. Wigand et al., 2009), as well as in recovered samples of actual well cement exposed to $\mathrm{CO}_{2}$ for prolonged timescales (Carey et al., 2007; Crow et al., 2010).

Within the outer parts of the cement there was very little preservation of the original cement fabric. The carbonated cement was now composed of many fine $(<200 \mu \mathrm{m}$ wide), nearly concentric bands of $\mathrm{CaCO}_{3}$ and silica gel (Fig. 2b). These appear to represent the positions of former (relict) 'reaction fronts' that have propagated into the altering cement along shrinkage micro-cracks formed at the interface between the outermost altered zone and inner less reacted hydrous cement 'core'. Though these have been sealed to some degree by secondary $\mathrm{CaCO}_{3}$ and $\mathrm{SiO}_{2}$ precipitates, these have not prevented the subsequent ingress of $\mathrm{CO}_{2}$ deeper into the cement sample. Such a succession of carbonation reaction fronts is comparable to similar features observed in actual wellbore cement exposed to $\mathrm{CO}_{2}$ for 30 a (Carey et al., 2007; Kutchko et al., 2007, 2008).

The most conspicuous reaction front (associated with the disappearance of CSH phases) progressed 7-10 $\mathrm{mm}$ into the sample in these static batch experiments over the 110 days of their duration. If extrapolated to a 30-a duration, this is within the range of distances found in other experimental studies (Zhang and Bachu, 2011). Though visual observations of the innermost parts of the cement initially appeared to show little reaction, more detailed petrographical observations 
and XRD analyses revealed that the remaining cement 'cores' had also undergone significant carbonation (Table 4). The most conspicuous reaction front, therefore, does not represent the maximum ingress of $\mathrm{CO}_{2}$, and carbonation proceeded over a broader zone within the sample. This result differs from some earlier studies (e.g. Kutchko et al., 2007, 2008) that suggest $\mathrm{CO}_{2}$ ingress only proceeds as far as the main reaction front. Within the partly-carbonated cement 'core' it is found that vaterite was relatively abundant and there was some aragonite, but there was little calcite. However, unlike the outer parts of the cement, significant amounts of CSH phases were also still present.

An important aspect of the carbonation 'front' is that it is associated with a local decrease in solids volume, leading to localised shrinkage and microfracturing. The latter appears to have facilitated subsequent ingress of $\mathrm{CO}_{2}$. Thereafter, many of these microfractures were filled by secondary carbonate precipitates. The localised nature of porosity generation and sealing may explain why the laboratory samples did not change their overall (i.e. macroscopic) dimensions. What is less clear from these experiments, however, is how this process would proceed over larger distances and over longer times. For example, the samples used in this study were relatively small and thus carbonation fronts were limited in thickness. It cannot be ruled out that carbonation zones of a few $\mathrm{cm}$ or tens of $\mathrm{cm}$ (i.e. very small on borehole scales) may be sufficient to limit $\mathrm{CO}_{2}$ ingress further into the cement. Similarly, the experiments were of relatively short duration. Again, it cannot be ruled out that continued, slow carbonation or carbonate mineral re-arrangement over longer timescales may act to seal porosity/permeability and also act to limit $\mathrm{CO}_{2}$ ingress into the cement. Longer-term experiments using larger cement samples may be one way to address these issues.

The observed evolution of secondary $\mathrm{CaCO}_{3}$ phases is relatively complex, and there is no certainty as to the exact process governing the distribution of these $\mathrm{CaCO}_{3}$ polymorphs. It may be a simple function of the local chemical environment and degree of supersaturation at the time of precipitation. However, faster precipitation kinetics of vaterite and aragonite (the less thermodynamically-favoured polymorphs) may lead to their formation alongside calcite during rapid carbonation. Temperature may also play a role. For example, laboratory carbonate precipitation experiments by Burton and Walter (1987) showed aragonite dominating precipitation relative to calcite at above $5{ }^{\circ} \mathrm{C}$ (albeit with seawater rather than alkaline fluids). Subsequently, the less stable polymorphs may slowly transform to more thermodynamically-stable calcite over time (e.g. for vaterite see Spanos and Koutsoukos, 1998 and also Zhou et al., 2010). Vaterite could, therefore, have formed initially in the outer parts of the samples, but over time transformed to the more stable polymorph, calcite. Progressive ingress of $\mathrm{CO}_{2}$ into the cement sample led to further vaterite formation away from the cement surface.

Irrespective of which carbonation process occurred, the reacted cement samples capture a series of reaction zones in a system that has not fully equilibrated. As this process was still ongoing when the experiments were terminated, a relatively thick 'stable' outer carbonated zone was not created. It is not possible to say, therefore, whether this would be a more effective barrier to $\mathrm{CO}_{2}$ ingress compared to the vaterite/aragonite/calcite mixture. It is also harder to assess whether the zone of active reaction would become progressively narrower as it moved further into the cement (i.e. also at longer timescales). Further experiments run for longer timescales and using larger samples might be a useful way to address this issue.

The relatively unaltered, inner cement 'core' displayed significant enrichment of $\mathrm{Cl}$ (identified by EDXA element distribution maps across the reaction front, Fig. 4), within a narrow zone about 2 mm wide ahead of the leading edge of the main carbonate reaction front. Petrographical 
observations indicated the $\mathrm{Cl}$ to be mainly associated with a very hydrous and poorly-crystalline CSH gel containing very little Al. However, XRD (Table 4) also identified the presence of small amounts of hydrocalumite $\left[\mathrm{Ca}_{4} \mathrm{Al}_{2} \mathrm{O}_{6} \mathrm{Cl}_{2} \cdot 10 \mathrm{H}_{2} \mathrm{O}\right]$ (also known as Friedel's Salt). It appears, therefore, that when $\mathrm{Cl}^{-}$(derived from the saline porewater in which the cement was immersed during the experiment) diffused into the alkaline inner 'core' of the cement it was rapidly incorporated into certain cement minerals. Progressive carbonation of the cement would destabilise phases such as hydrocalumite. A reaction sequence is suggested, whereby initially-formed Cl-rich phases break down and release $\mathrm{Cl}^{-}$. This diffuses further into the non-carbonated or only partiallycarbonated cement and is re-precipitated. It is also possible that additional $\mathrm{Cl}^{-}$may have diffused through the carbonated layer to enhance this precipitation. It is postulated that this process would continue until all the cement was carbonated, at which point $\mathrm{Cl}^{-}$would be released back to solution. More limited uptake of $\mathrm{Cl}^{-}$by the cement was found in the $\mathrm{N}_{2}$-control experiment, occurring in the outermost parts of the sample. Chlorine-rich secondary phases in cement have previously been identified in laboratory studies (Wigand et al., 2009) and recovered samples of actual well cement (Carey et al., 2007).

In terms of modelling short-timescale processes, it will also be important to include calcite, aragonite and vaterite in model databases. This will be especially helpful in modelling shortertimescale processes, though over longer timescales calcite may eventually dominate because of its greater stability. Other carbonate minerals also need to be considered. There was some evidence for Fe-rich carbonate precipitates (e.g. siderite) close to leached borehole steel (a source of reduced Fe in the experimental samples). Potentially, Fe could also be released from cement as it can contain Fe-rich phases, although any Fe in cement is fully oxidised (in ferrite phases) and would require the presence of a suitable reducing agent in order to produce siderite. This might be provided by the presence of metallic Fe where in contact with steel, or in the case of a depleted hydrocarbon well, by the presence of hydrocarbons in the formation fluids. Although most predictive computer codes consider just end-member mineral compositions, a considerable solid solution exists between carbonate minerals. Computer codes that can model such solid solutions may be able to provide more realistic predictions, and match more closely observations of laboratory experiments and material recovered from boreholes. Dawsonite $\left(\mathrm{NaAlCO}_{3}[\mathrm{OH}]_{2}\right)$ was not identified in any of the reaction products even though it has been predicted to form in many $\mathrm{CO}_{2}$ storage environments (e.g. Gaus et al., 2005; Knauss et al., 2005; Xu et al., 2005; Zerai et al., 2006; Gherardi et al., 2007), forms readily under highly alkaline conditions (Zhang et al., 2004), and has been possibly identified in trace quantities in actual carbonated well cement (Carey et al., 2007).

\subsubsection{Changes in aqueous fluid chemistry}

A summary of changing fluid chemistry is presented in Table 5. In the absence of $\mathrm{CO}_{2}$ (in this study the $\mathrm{N}_{2}$-pressurised experiment, Run 1233) waters in contact with cement became hyperalkaline due to the dissolution of portlandite within the cement (recovered sample achieving a $\mathrm{pH}$ value of over 13 when measured at $25{ }^{\circ} \mathrm{C}$ and $1 \mathrm{bar}$, Run 1233). The alkaline conditions ensured that virtually all of the $\mathrm{HCO}_{3}{ }^{-}$ions were converted to $\mathrm{CO}_{3}{ }^{2-}$ ions. The low concentrations of the latter $\left(72 \mathrm{mg} \mathrm{L}^{-1}\right)$ may reflect some precipitation as secondary carbonate minerals (such as calcite) in the presence of metal ions such as $\mathrm{Ca}^{2+}$. The dissolution of large quantities of $\mathrm{CO}_{2}$ into these alkaline waters moderated their $\mathrm{pH}$ to more neutral values (recovered sample $\mathrm{pH}=6.7$ when measured at $25^{\circ} \mathrm{C}$ and 1 bar, Run 1232), but this generated very high concentrations of $\mathrm{HCO}_{3}{ }^{-}$ions. In the data reported here these reached approximately $10000 \mathrm{mg} \mathrm{L}^{-1}$ (Table 5), though similar tests in other studies have recorded even higher values (e.g. Rochelle et al., 2009). 
The cement samples leached soluble components into solution regardless of whether $\mathrm{CO}_{2}$ was present or not (e.g. increases in dissolved $\mathrm{K}$ in both $\mathrm{CO}_{2}$ - and $\mathrm{N}_{2}$-pressurised experiments). The lowering of $\mathrm{pH}$ values due to the presence of $\mathrm{CO}_{2}$ led to large increases in dissolved $\mathrm{Ca}, \mathrm{Mg}$ and $\mathrm{SO}_{4}{ }^{2-}$, possibly through the dissolution of phases such as portlandite, $\mathrm{CSH}$ phases, brucite and ettringite. However, in the case of $\mathrm{Mg}$, the alkaline conditions in the $\mathrm{N}_{2}$-pressurised experiment (Run 1233) caused Mg in the starting solution to precipitate (as brucite), leading to its near absence in solution (Rochelle et al., 2009). Given that the presence of $\mathrm{CO}_{2}$ led to leaching of material from the cement, it is possible that if sufficient water was present and leaching was excessive, then it may be a mechanism to change porosity/permeability and reduce the sealing capacity of the cement. That said, in systems of limited water volume (such as in these experiments) the water probably became saturated with respect to secondary carbonate minerals relatively quickly, and leaching would have become progressively reduced as steady-state conditions were approached. The implications for borehole sealing are clear, the presence of pre-existing defects and a pressure gradient to drive fluids through them have the potential to provide environments capable of leaching the cement. Thus it is very important to have a good initial cement seal.

Somewhat less expected observations were the reductions in dissolved $\mathrm{Na}$ and especially $\mathrm{Cl}^{-}$, as these elements are relatively conservative, and their decrease in concentrations is consistent with incorporation into secondary precipitates. This happened in both $\mathrm{N}_{2}$-pressurised and $\mathrm{CO}_{2}-$ pressurised experiments, but was more pronounced in the latter. Indeed, dissolved $\mathrm{Cl}^{-}$ concentrations halved in one $\mathrm{CO}_{2}$-pressurised experiment (Run 1232). Given that $\mathrm{CO}_{2}$ storage operations may take place in formations with highly saline formation waters, or even in the presence of halite, then much dissolved salt may be available for the formation of Na-and Cl-rich secondary phases. This may be beneficial if they have a significant volume, and may thus be able to help improve sealing within the borehole cement. Interestingly, the Cl-rich phase Friedel's Salt was identified in experimental residues by Wigand et al. (2009) and in recovered samples of actual borehole cement by Carey et al. (2007). It is important, therefore, that predictive modelling incorporates such $\mathrm{Cl}$-rich phases, and that the underpinning thermodynamic data for them is reliable. Without this, theoretical modelling may not be able predict their formation, and the resulting calculations risk being unrealistic.

\section{Carbonation reactions in natural systems}

Observations of very old cement minerals potentially can provide valuable information on the long-term stability and behaviour of cements, and analogies can be drawn about how current cements may behave in the future. Such 'analogues' could be as either historical cements from archaeological sites (hundreds to thousands of years old), or natural cement minerals (many thousands of years old). Observations of natural analogues of cement minerals, therefore, provide a source of information over timescales comparable to those required for $\mathrm{CO}_{2}$ containment, providing unique information on the long-term stability and behaviour of cements. Natural analogues in which either groundwater chemistry and/or mineral systems are similar to those encountered in man-made Portland cement systems are very rare, and are known from only a small number of restricted geological environment (Alexander et al., 1992). Four principal occurrences of cement natural analogue systems can be defined:

1) Low-temperature serpentinisation of ultrabasic rocks and ophiolites.

2) Retrograde alteration and hydration of metamorphic Ca silicates of high temperature-low pressure contact metamorphic zones around igneous intrusions in impure limestones and calcareous shales. 
3) Retrograde alteration and hydration of small bodies of high temperature-low pressure marble produced by spontaneous combustion and in-situ calcination of organic-rich argillaceous and siliceous limestones.

4) Alteration of high temperature-low pressure metamorphic minerals produced by pyrometamorphism of coal seams and other carbonaceous sediments.

In all of these geological systems, natural phases similar to those found in Portland cement slags and hydrated cement pastes may potentially be altered as a result of carbonation through direct contact with atmospheric or soil gas $\mathrm{CO}_{2}$, or by interaction with rainwater containing dissolved $\mathrm{CO}_{2}$, or $\mathrm{HCO}_{3}$-type groundwaters. Whilst it is recognised that there are certain differences in mineralogy, and that the carbonation reactions have occurred under conditions of very different pressure, temperature and $\mathrm{CO}_{2} /$ carbonate abundance to those of underground $\mathrm{CO}_{2}$ storage, it is suggested that there are many similarities in the reaction processes involved.

The work reported here focussed on a study of the carbonation reaction behaviour of naturallyoccurring $\mathrm{CSH}$ assemblages associated with the high-temperature, low-pressure contact metamorphic aureoles around minor Tertiary dolerite intrusions into Cretaceous siliceous limestones in Northern Ireland. These naturally-hydrated contact-metamorphosed mineral assemblages differ markedly in their mineralogy in comparison to hydrated Portland cement paste (Table 6). The hydration products in Portland cement paste are significantly more complex and comprise portlandite, $\mathrm{CSH}$ and a number of $\mathrm{Ca}$ aluminate hydrates (which may also contain $\mathrm{Fe}$ ) as major components - usually referred to as Afm phases. In addition, hydrated Portand cement paste usually contains major ettringite $\left(\mathrm{Ca}_{6} \mathrm{Al}_{2}\left(\mathrm{SO}_{4}\right)_{3}(\mathrm{OH})_{12} \cdot 26 \mathrm{H}_{2} \mathrm{O}\right)$, depending on the $\mathrm{SO}_{4}$ content of the cement. In contrast, the principal 'reactive' component, with regard to hydration, in the natural contact-metamorphosed siliceous limestones is largely monominerallic larnite $\left(\beta-\mathrm{Ca}_{2} \mathrm{SiO}_{4}\right)$, which hydrates to crystalline tobermorite $\left(\mathrm{Ca}_{5} \mathrm{Si}_{6} \mathrm{O}_{16}(\mathrm{OH})_{2} \cdot 2-8 \mathrm{H}_{2} \mathrm{O}\right)$ and a poorly-crystalline to amorphous $\mathrm{CSH}$ gel of similar $\mathrm{Ca}$ :Si ratio to tobermorite. Other phases, such as spurrite/paraspurrite $\left(\mathrm{Ca}_{5}\left(\mathrm{SiO}_{4}\right)_{2} \mathrm{CO}_{3}\right)$, scawtite $\left(\mathrm{Ca}_{7} \mathrm{Si}_{6}\left(\mathrm{CO}_{3}\right) \mathrm{O}_{18} \cdot 2 \mathrm{H}_{2} \mathrm{O}\right)$ and bredigite $\left(\mathrm{Ca}_{7} \mathrm{Mg}(\mathrm{SiO})_{4}\right)$ may also be present (cf. this study and Milodowski et al., 1989, 2009), but they also alter mainly to tobermorite and CSH gel. Consequently, CSH gel and tobermorite are the dominant hydration products of the contact metamorphic calcsilicate rocks. Whilst these natural materials differ significantly in composition to hydrated Portland cement paste, it is suggested that they do represent a useful analogue in which to study the long-term carbonation alteration of the $\mathrm{CSH}$, which is one of the major components of Portland cements (Table 6).

It is believed that carbonation of the hydrated cement minerals (CSH phases) started at the end of the last glaciation, about $10 \mathrm{ka}$ ago, when the contact metamorphosed rocks were exposed to atmospheric $\mathrm{CO}_{2}$, or to $\mathrm{CO}_{2}$ or $\mathrm{HCO}_{3}{ }^{-}$in the shallow groundwater/soil environment. The detailed findings from this study are reported in Milodowski et al. (2009), and just a summary of the information is outlined below.

\subsection{Geological setting of the natural analogue sites from Northern Ireland}

The Antrim Lava Group (Palaeogene) of Northern Ireland, UK is intruded by at least thirty dolerite plugs that in places form prominent landmarks rising above the surface of the Antrim Plateau (Mitchell, 2004). These minor intrusions are roughly circular in outline or elongated in a NNW-SSE direction that is parallel to the orientation of the main dyke swarm. They vary from 50 $\mathrm{m}$ to $1 \mathrm{~km}$ in diameter and are composed mainly of olivine dolerite. Many of the plugs are associated with contact metamorphism of the adjacent country rocks. Several of these plugs have intruded the chert (flint)-bearing Upper Cretaceous Ulster White Limestone Formation. The chert 
nodules have been hornfelsed by the dolerite producing a calcsilicate mineral assemblage (Tilley, 1929, 1930, 1933; Tilley and Harwood, 1931; Tilley and Alderman, 1934; Tilley and Vincent, 1948; Sabine, 1975; Griffith and Wilson, 1982; Sabine et al., 1982, 1985; Mitchell, 2004). A field visit was undertaken to examine and sample the metamorphic aureoles around the dolerite plugs at Scawt Hill and Carneal Plug (Fig. 5).

\subsubsection{Scawt Hill}

Scawt Hill is located about $5 \mathrm{~km}$ WNW of Ballygalley and $7 \mathrm{~km} \mathrm{SSW}$ of Glenarm, County Antrim. It is a very conspicuous feature, at the edge of the east-facing Antrim basalt escarpment, some $30 \mathrm{~m}$ above the surrounding flat Tertiary flood-basalt plateau, to a height of $378 \mathrm{~m}$ (Fig. 5). It is a moderately large olivine-dolerite plug of Palaeogene age that intrudes both the Cretaceous Ulster White Limestone Formation and early Palaeogene lavas of the Lower Basalt Formation (Geological Survey of Northern Ireland, 2001; Mitchell, 2004). Exposures of metamorphosed limestone containing chert concretions drape the sub-vertical walls of the plug in several places, and are well exposed in steep gullies to the north and south of the summit.

Large landslips affect much of the area underlain by Mesozoic sedimentary strata to the east of the basalt escarpment. Landslipped strata form the undulating, lower-lying pasture land extending to the SE from the foot of the steep dolerite cliffs. These major landslips are most likely to have occurred along the steep margins of the Antrim Plateau shortly after the retreat of ice cover at the end of the last glacial maximum (24 to $20 \mathrm{ka} \mathrm{BP}$ ), when the ice support was lost (Mitchell, 2004).

In general the contact-metamorphosed cherts display progressive marginal metasomatism, and comprise larnite-spurrite-dominated rock (formed at the margins of the former chert concretion adjacent to the limestone matrix) surrounding a core of wollastonite and xonotlite. However, they may contain a complex assemblage of other primary metamorphic minerals including quartz, scawtite, bredigite, melilite, spinel, gehlenite, merwinite and magnetite. Later retrograde hydration and meteoric alteration have resulted in the formation of gel-like $\mathrm{CSH}$ and $\mathrm{Ca}$ aluminosulfate phases, together with a range of crystalline analogues of hydrated Portland cement phases (including xonotlite, tobermorite, afwillite, gyrolite and ettringite).

When freshly broken open, many of the fallen blocks of marble (metamorphosed limestone) were found to contain highly altered calcsilicate (larnite) nodules (representing the originally hornfelsed chert nodules). These are now virtually completely replaced by a very moist, soft white gel-like alteration product (Fig. 6a), the majority of which is CSH. On exposure to air this gel-like material rapidly lost water and dried to hard creamy-white gel with significant shrinkage. The soft CSH-replaced hydrated larnite cores of the nodules are surrounded by hard 'rinds' of carbonated alteration product. On weathered rock surfaces the hydrated cores of these highly altered calcsilicate nodules were commonly seen dissolved away to leave mouldic cavities lined only by the more resistant carbonated 'rinds'.

\subsubsection{Carneal Plug}

The Carneal Plug is located at the junction of the Carneal and Raloo Waters, about $0.8 \mathrm{~km} \mathrm{SW}$ of the village of Glenoe. Here a small Tertiary dolerite plug intrudes the Lower Basalt Formation (Griffith and Wilson, 1982; Mitchell, 2004). However, the intrusion has dragged up a block of finegrained, hard white limestone (bedded with flints) of the Ulster White Limestone that underlies the Lower Basalt Formation in this area (Emeleus and Preston, 1969; Griffith and Wilson, 1982; Mitchell, 2004). This has been highly metamorphosed, metasomatised and altered to marble. Assimilation of the limestone by the dolerite magma has produced local hybrid black pyroxenite 
and mixed pyroxenite-larnite rocks (Sabine, 1975; Sabine et al., 1982). The marble is exposed where it was once worked, in a small, disused quarry that is now heavily overgrown (Emeleus and Preston, 1969). These xenoliths have been intensely thermally metamorphosed, metasomatised to form a calcsilicate-rich marble, although the outlines of original chert (flint) concretions are still recognisable in the larger xenoliths (Fig. 6b). However, the original calcite and silica have been completely altered and replaced by calcsilicate rock containing a complex assemblage of minerals that includes: quartz, larnite, wollastonite, spurrite, bredigite, merwinite, gehlenite, calcite, spinel, scawtite, perovskite, hibschite (hydrogrossular), titanite (sphene) and magnetite, together with their low-temperature alteration products such as tobermorite and xonotlite (Sabine, 1975; Sabine et al., 1982, 1985).

It is estimated that emplacement of the Carneal Plug (and similar plugs like Scawt Hill) and the observed contact metamorphism of the Ulster White Limestone occurred at $<700 \mathrm{~m}$ depth. Latestage hydration and alteration of the contact metamorphic assemblage probably occurred at shallower depths, following significant post-Tertiary and Quaternary uplift and erosion which affected the region (Mitchell, 2004; Sabine, 1975).

\subsection{Mineralogical alteration}

\subsubsection{Early high-temperature alteration}

High-temperature contact metamorphism of diagenetic silica concretions (chert or flint) within the Ulster White Limestone Formation at Carneal Plug and Scawt Hill produced a hornfelsed rock comprising primary metamorphic assemblage dominated by larnite $\left(\beta-\mathrm{Ca}_{2} \mathrm{SiO}_{4}\right)$, sometimes accompanied by wollastonite $\left(\mathrm{CaSiO}_{3}\right)$, spurrite $\left(\mathrm{Ca}_{5}\left(\mathrm{SiO}_{4}\right)_{2} \mathrm{CO}_{3}\right)$, parraspurrite $\left(\mathrm{Ca}_{5}\left(\mathrm{SiO}_{4}\right)_{2} \mathrm{CO}_{3}\right)$, brownmillerite $\left(\mathrm{Ca}_{2}(\mathrm{Al}, \mathrm{Fe})_{2} \mathrm{O}_{5}\right)$, quartz and calcite. In the more heavily metasomatised (skarn) rocks from Carneal Plug, magnetite $\left(\mathrm{Fe}_{3} \mathrm{O}_{4}\right)$ and andradite-grossular garnet are also significant minerals. Hydroxyapatite is present as a minor component in some of the samples from Scawt Hill.

The samples of calcsilicate nodules from Scawt Hill are generally much paler than similar hornfelsed chert from the xenolithic limestone blocks found at Carneal Plug, and the matrix marble has not been so heavily metasomatised with $\mathrm{Fe}$ and, therefore, contains little or no magnetite and pyroxene mineralisation. The nodules can be concentrically zoned (e.g. Fig. 6c), comprising a largely unaltered core of coarsely crystalline larnite, spurrite/paraspurrite surrounded by reaction rims of quartz and scawtite $\left(\mathrm{Ca}_{7} \mathrm{Si}_{6}\left(\mathrm{CO}_{3}\right) \mathrm{O}_{18} \cdot 2 \mathrm{H}_{2} \mathrm{O}\right)$. The petrographical relationship between scawtite and other minerals is clearer in the samples from Scawt Hill than in Carneal Plug. The scawtite appears to be an early carbonate mineral closely associated with larnite, and predates subsequent hydration of the larnite to CSH. It may be intergrown with larnite but appears to form a reaction band between the larnite and the host marble. In some cases a central core of coarse quartzrich material may be present, representing recrystallised chalcedonic silica that has not reacted with lime from the adjacent host limestone during metamorphism (Fig. 6d). Minor to trace amounts of brownmillerite and wollastonite may also be present as primary metamorphic minerals. However, wollastonite is much less abundant in the samples collected from Scawt Hill than in the samples collected from Carneal Plug. Spurrite and paraspurrite occur as well-crystallised minerals, intergrown with larnite, in the outer part of these hornfelsed flints, adjacent to the marble host rock. These carbonate minerals appear to be part of the original high-temperature metamorphic assemblage, probably forming by recarbonation of the Ca silicate rock at high temperature as metamorphism waned.

\subsubsection{Low-temperature alteration}


The larnite nodules usually display significant alteration as a result of hydration and reaction with groundwater or as a result of exposure to weathering. The alteration may form reaction rims around the margins of a residual core containing relicts of larnite. In the case of Scawt Hill, even larnite nodules freshly exposed by splitting large blocks of recently fallen marble often showed evidence of extensive alteration and hydration, with the replacement of larnite by a very soft, moist, CSH gel. XRD and BSEM identified the CSH gel hydration products of the larnite as tobermorite (including both $11 \AA$ and $14 \AA$ variants) and amorphous CSH gel.

Of interest to this study is carbonation of the CSH hydration rim, which is evident in most of the samples examined. The outer margins of the $\mathrm{CSH}$ rim are replaced by dense fine-grained $\mathrm{Ca}$ carbonates (Zone D in Fig. 6d). Carbonation of the nodules proceeds progressively from the outer margins, and when weathered out they leave a cup-like carbonate layer on the rock face. Within this layer the $\mathrm{CSH}$ gel and tobermorite are replaced by a very fine-grained groundmass of $\mathrm{CaCO}_{3}$. It was not possible to differentiate the carbonate minerals in this fine-grained alteration using BSEMEDXA. However, XRD analysis identified this carbonated material to comprise a mixture of mainly calcite (and residual scawtite from the high temperature metamorphic reaction), with minor vaterite and/or aragonite. Immediately beneath the carbonated rim there is often a narrow region of enhanced porosity (Zone C in Fig. 6d). Within this zone, carbonation of the CSH (including crystalline tobermorite and amorphous $\mathrm{CSH}$ gel) produced shrinkage and microfracturing of the carbonated $\mathrm{CSH}$. The $\mathrm{CSH}$ in the walls of the microfractures is characteristically altered and leached of $\mathrm{Ca}$ to produce a residual microporous very fine grained silica gel alteration product. The fractures may become partially filled with fine-grained $\mathrm{CaCO}_{3}$ to form fine microporous veinlets. These veinlets may be banded indicating that shrinkage and dilation of fractures, followed by calcite precipitation, occurred in multiple cycles. Some fractures may be lined by euhedral, equant crystals, suggesting growth of calcite into free pore space and under water-saturated conditions. Although $\mathrm{CO}_{2}$ has carbonated the outermost parts of the $\mathrm{CSH}$, much unreacted $\mathrm{CSH}$ is still preserved beneath the carbonate reaction rim. Unaltered CSH phases still remain within the inner parts of the nodules. These may have remained stable and uncarbonated for significant timescales, possibly measurable in thousands of years, even though the outer altered 'rinds' of the nodules may have enhanced porosity and not fully-sealed microfractures. The limited degree of alteration suggests relatively slow reaction, possibly influenced by the carbonated reaction rim slowing down ingress of $\mathrm{CO}_{2}$ as it developed.

The metasomatised rocks from Carneal Plug have a more complex mineralogy compared to that at Scawt HIll, with hornfelsed flints containing a crystalline intergrowth of larnite, brownmillerite, wollastonite, pyroxene, garnet, titanite (sphene) and magnetite. At the Carneal Plug two stages of late-stage low temperature alteration can be differentiated:

1) The earliest alteration is the hydration and replacement of larnite by CSH gel (Fig. 7a). Optical petrography suggests that much of this $\mathrm{CSH}$ gel is isotropic and, therefore, probably largely amorphous. However, XRD data show that at least part of this CSH contains more crystalline $11 \AA$ tobermorite. Trace amounts of larnite intergrown within the underlying wollastonite-quartz reaction zone in the metamorphosed chert nodule may also be partially hydrated to amorphous or poorly crystalline CSH along networks of microfractures. The $\mathrm{CSH}$ alteration products preserve (pseudomorph) the original crystal grain boundaries of the primary larnite. This feature was observed in earlier studies of the hydration of larnite to CSH in calcsilicate nodules from Scawt Hill and Carneal Plug (Milodowski et al., 1989), and implies that the hydration of larnite to $\mathrm{CSH} /$ tobermorite is isovolumetric. 
2) Of interest to this study is the second alteration stage that involves the replacement of CSH by $\mathrm{Ca}$ carbonates. XRD data suggest that the $\mathrm{CaCO}_{3}$ mineral is dominantly calcite, but minor to trace amounts of vaterite and aragonite are also formed. In addition, traces of ankerite were identified. Vaterite has also previously been recorded in association with $\mathrm{CSH}$, formed from by alteration of larnite nodules from nearby Ballycraigy by McConnell (1960). The $\mathrm{CaCO}_{3}$ initially nucleated as patches or 'islands' within the $\mathrm{CSH}$ gel matrix and along the fabric delineated by the original grain boundaries of the primary larnite.

Petrographic observations of carbonated CSH (i.e. previously hydrated larnite nodules) tends to show a greater proportion of vaterite as a reaction product in the younger (lesscarbonated) cores than in the older (earlier carbonated) rims, the latter being dominated by calcite. EDXA indicates that the residual CSH gel becomes increasingly lower in $\mathrm{Ca}: \mathrm{Si}$ as alteration progresses. The replacement of $\mathrm{CSH}$ by $\mathrm{CaCO}_{3}$ is also accompanied by enhanced microporosity of the $\mathrm{CSH}$, as a result of volume reduction and polygonal shrinkage cracking of the CSH gel, together with some dissolution of the gel matrix around the secondary carbonate (Fig. 7a). Porous microfractures are also produced along the interface between the wollastonite-quartz nodule and the host rock, often resulting in 'popping-out' of the now only weakly-bonded nodule core. These fractures are commonly lined by secondary calcite mineralisation (Fig. 7b), the Ca presumably having been derived from that released during the alteration of the CSH substrate. With further reaction the carbonate 'islands' coalesce to form a microgranular groundmass. The net result of this alteration eventually produces a fine-grained mixture of $\mathrm{CaCO}_{3}$ and probable amorphous silica gel.

It is not totally clear whether carbonation results from interaction of the $\mathrm{CSH}$ phases with atmospheric $\mathrm{CO}_{2}$ or $\mathrm{HCO}_{3}{ }^{-}$in rainwater during exposure and weathering, or whether carbonation results from the interaction with groundwater $\mathrm{HCO}_{3}{ }^{-}$when the rocks were below the water table prior to uplift and exposure. At Scawt Hill the larnite nodules have been extensively leached, and the $\mathrm{CSH}$ rims largely replaced by secondary $\mathrm{CaCO}_{3}$ and silica/quartz. In contrast, larnite nodules which were recovered by breaking open blocks of marble, and which had not been exposed to surface weathering showed only minor late-stage carbonation of CSH rims. This implies that carbonation is strongly influenced by exposure to weathering, atmospheric $\mathrm{CO}_{2}$ and/or $\mathrm{H}_{2} \mathrm{CO}_{3}$ in rainwater. The contact metamorphic rocks observed on the southeastern rock faces of Scawt Hill have largely been exposed as a result of large landslips that affect the steep eastern margin of the Antrim Plateau, including Scawt Hill (Geological Survey of Northern Ireland, 2001). These major landslips are most likely to have occurred shortly after the retreat of ice cover at the end of the last glacial maximum (24 to $20 \mathrm{ka} \mathrm{BP}$ ), when the ice support was lost (Mitchell, 2004). This would suggest that the observed carbonation and leaching reactions at the Scawt Hill site could have been ongoing since this time.

At Carneal Plug, the carbonation and leaching of larnite and its associated secondary CSH hydration products have been observed in material exposed in the degraded walls of a small quarry working on the western side of the plug. The $\mathrm{CSH}$ phases have been exposed to atmospheric $\mathrm{CO}_{2}$ and rainwater since these faces were last worked. The age of the quarry is not known, but it seems likely that it was probably worked during the last 100-200 a to produce local stone for the construction of field boundary walls. However, the presence of euhedral secondary calcite crystals lining the surfaces of fractures within the carbonated larnite nodules might indicate that the calcite crystals grew within water-saturated pores (Milodowski et al., 1998) - i.e. when the rock was below the groundwater table. This would imply that carbonation of nodules may be much older. Further 
study of carbonated samples from Scawt Hill and Carneal Plug is required to more definitively ascertain the origin of the $\mathrm{CO}_{2}$ and to determine whether carbonation is still ongoing.

\section{Implications of $\mathrm{CO}_{2}$ interaction with well cements}

The carbonation reactions/processes outlined in previous sections have important implications for the understanding of long-term engineered seal behaviour. One general, very noteworthy observation, is that carbonation did not result in the wholesale disintegration of the borehole cement used in the experiments or the natural CSH nodules. Indeed, not only did the samples remain intact, the overall dimensions of the experimental samples and natural analogue materials remained unchanged. There was no macroscopic evidence of cement swelling (which might indicate increases in stress in the near wellbore region), or cement shrinkage (which might indicate the cement 'pulling away' from the steel liner or wallrock). However, there were significant changes to the fabric and porosity characteristics of the cement and natural analogue materials on the microscopic scale. Carbonation was characteristically associated with Ca mobilisation, and the formation of a higher porosity zone associated with a well-defined reaction front. This new porosity included microporosity within the matrix, mouldic dissolution porosity after original cement components, and microfracture porosity, and it provided a route for $\mathrm{CO}_{2} / \mathrm{HCO}_{3}{ }^{-} / \mathrm{CO}_{3}{ }^{2-}$ to penetrate further into the sample.

The carbonation mechanism for laboratory samples appeared to proceed in a series of steps (Fig. 8), most of which appear consistent with observations of the natural analogue material:

1) $\mathrm{CO}_{2} / \mathrm{HCO}_{3}{ }^{-} / \mathrm{CO}_{3}{ }^{2-}$ enters the cement matrix.

2) Reaction of portlandite, $\mathrm{CSH}, \mathrm{CAH}$ and $\mathrm{Ca}$ aluminosulfate (ettringite) phases produces silica and $\mathrm{CaCO}_{3}$ (either calcite, vaterite or aragonite).

3) Gradients of $\mathrm{pH}$ and $\mathrm{Ca}$ activity are established, resulting in the breakdown of portlandite, $\mathrm{CSH}$ and $\mathrm{CAH}$ phases in advance of the migrating $\mathrm{CO}_{2} / \mathrm{HCO}_{3}{ }^{-} / \mathrm{CO}_{3}{ }^{2-}$, and the creation of a higher porosity 'leached zone' in advance of the main carbonation front.

4) The solids volume changes associated with $\mathrm{CSH} /$ portlandite dissolution and $\mathrm{CaCO}_{3} /$ silica gel precipitation cause localised stresses within the cement matrix, resulting in small-scale cracking that extends into the (relatively uncarbonated) cement matrix.

5) $\mathrm{CO}_{2} / \mathrm{HCO}_{3}{ }^{-} / \mathrm{CO}_{3}{ }^{2-}$ migrates along the higher porosity leached zone and along stress cracks to create a new carbonation front. This proceeds in episodic steps, resulting in a series of relict reaction fronts. Carbonation is more intense along the narrow cracks, resulting in a heterogeneous density distribution, with narrow zones of higher density and broader regions of lower density (overall however, bulk cement density increases on carbonation).

6) $\mathrm{Ca}$ diffuses out of the leached zone towards the $\mathrm{CO}_{2} / \mathrm{HCO}_{3}{ }^{-} / \mathrm{CO}_{3}{ }^{2-}$ (i.e. possibly against the flow direction), eventually forming $\mathrm{CaCO}_{3}$. This front results in further $\mathrm{CaCO}_{3}$ precipitation (i.e. reducing porosity in the carbonated zone, which is itself a former leached zone).

7) If there is a source of dissolved $\mathrm{Cl}^{-}$(i.e. saline porewater is present), this diffuses into the cement where it forms a calcium chlorohydroaluminate (typically $\mathrm{Ca}_{4} \mathrm{Al}_{12} \mathrm{H}_{0.34} \mathrm{O}_{6.34} \mathrm{Cl}_{1.67}$ ) in the high $\mathrm{pH}$ conditions. As the carbonation reaction front progresses into the sample, the initially-formed Cl-rich phases break down, and the $\mathrm{Cl}^{-}$released diffuses further into the cement to form new Cl-rich phases. Diffusion of additional $\mathrm{Cl}^{-}$through the carbonated zone may also have occurred.

8) Initial, rapidly-formed polymorphs of $\mathrm{CaCO}_{3}$ (vaterite and aragonite) become dominated by calcite precipitation over time, and possibly transform slowly into this more stable polymorph. 
The above steps involve some noteworthy processes. Firstly, the very different conditions (i.e. timescales, pressures, temperatures, $\mathrm{CO}_{2}$ pressures, chemical gradients, supersaturated/ undersaturated conditions) between the laboratory experiments and the natural samples resulted in differences in widths of the reaction zone, being $\mathrm{cm}$-scale in the laboratory experiments and below mm-scale in the natural samples. If applied to the borehole environment, this suggests that initial carbonation of the lower parts of the cement seal might result in a broader reaction zone, but that this would become narrower over time as it progressed into the cement. It is tentatively suggested, that the narrowing of the reaction zone might produce a sufficiently dense and low permeability calcite precipitation zone that could further impede $\mathrm{CO}_{2} / \mathrm{HCO}_{3}{ }^{-} / \mathrm{CO}_{3}{ }^{2-}$ ingress. The implications of this are that limited carbonation of the lower part of a borehole seal might act to protect the remaining borehole cement seal. Improved representations of the complex interplay between chemical reaction and solute over time may be needed in future predictive modelling studies.

Secondly, there is local diffusion of $\mathrm{Ca}$ ions against the overall direction of $\mathrm{CO}_{2} / \mathrm{HCO}_{3}{ }^{-} / \mathrm{CO}_{3}{ }^{2-}$ $\left( \pm \mathrm{Cl}^{-}\right)$movement. It is possible that this may even happen against the overall direction of fluid flow, though this could not be demonstrated using the near static systems of the current study. The driver for this diffusion is the large chemical potential across the few millimetres of the main part of the reaction front. The formation of a leached zone during this process has the potential to create a plane of weakness in the cement. If this were to coincide with areas of lower quality cement (e.g. an initially poor cement job), then it might act to magnify the extent of pre-existing sealing issues. Also, if there was sufficient advection of aqueous fluid through the cement (such as along a crack, or along poor cement-steel or cement-rock bond/interface), then this might carry away the released $\mathrm{Ca}^{2+}$ and reduce $\mathrm{CaCO}_{3}$ precipitation. $\mathrm{A} \mathrm{CO}_{2}$-rich aqueous fluid would be somewhat acidic, and this might also dissolve $\mathrm{CaCO}_{3}$ directly (as per the leaching seen in the outermost parts of the experimental samples). If fluid advection was sufficiently large, then this might act to magnify flow pathways (e.g. Carey et al., 2007) and could result in progressive, and increasing $\mathrm{CO}_{2}$ migration along the well bore. It will be important, therefore, to ensure that borehole seals in and around underground stores of $\mathrm{CO}_{2}$ are of high quality to help maximise the long-term containment of $\mathrm{CO}_{2}$.

Thirdly, this study has identified features and processes that should be incorporated into improved numerical models of cement carbonation. The appearance of three $\mathrm{CaCO}_{3}$ polymorphs was particularly evident in the laboratory experiments, though low abundances of aragonite and vaterite were also observed in the natural samples. Whilst the observations are consistent with a model of fast precipitation of aragonite and vaterite followed by slower conversion to more stable calcite, uncertainties remain. It is also possible that aragonite and vaterite formation was controlled by local chemical conditions early in the carbonation process, with calcite precipitation dominating thereafter. Regardless of the mechanism involved, evolving $\mathrm{CaCO}_{3}$ phase abundance may impact overall solids volume over time, and hence impact cement porosity and permeability. One carbonate phase that was not observed in either the experimental or natural samples was dawsonite. This is in spite of modelling studies having identified this phase as an important secondary phase in $\mathrm{CO}_{2}$-rich reservoir rocks, and experimental studies having formed it under elevated $\mathrm{pH}$ conditions. In systems where a saline fluid was used there was evidence for significant formation of Cl-rich phases such as $\mathrm{Cl}$-enriched $\mathrm{CSH}$ gel-like alteration products and hydrocalumite $\left[\mathrm{Ca}_{4} \mathrm{Al}_{2} \mathrm{O}_{6} \mathrm{Cl}_{2} \cdot 10 \mathrm{H}_{2} \mathrm{O}\right]$ just ahead of the leading edge of the main carbonation front. Again, the formation and subsequent breakdown of these phases could change overall solids volume of the reaction front region over time, and hence impact cement porosity and permeability. It will be useful to include these, and similar cement phases, into the databases of predictive models in order to make more precise assessments of changing cement porosity/permeability. 
Finally, the samples of naturally-occurring CSH phases have only been carbonated for a few $\mathrm{mm}$ along their outermost margins, and much $\mathrm{CSH}$ remains unaltered. This longevity of the CHS phases (measurable in many thousands of years) is highly suggestive of the carbonate outer layer providing some protection from $\mathrm{CO}_{2} / \mathrm{HCO}_{3}{ }^{-} / \mathrm{CO}_{3}{ }^{2-}$. As such, these natural analogues provide some evidence for potential good longevity of the majority of a borehole seal. However, caution is noted, not least because of the very different pressures, temperatures, $\mathrm{CO}_{2}$ pressures and cement mineralogy between the natural samples and $\mathrm{CO}_{2}$ storage site. Though these analogues might provide much useful information, further work is needed to quantify exactly how the analogue data can be applied to an underground storage setting.

\section{Conclusions}

During underground $\mathrm{CO}_{2}$ storage operations in deep reservoirs, the containment of injected $\mathrm{CO}_{2}$ will be crucially dependent on the integrity of man-made seals above the $\mathrm{CO}_{2}$. It is important, therefore, to assess how the $\mathrm{CO}_{2}$ might impact these seals, as this could control the ultimate longevity of $\mathrm{CO}_{2}$ storage. To further general understanding of cement carbonation, an experimental and natural analogue study was undertaken to identify the geochemical impact of $\mathrm{CO}_{2}$ on borehole cement and natural CSH phases over short and prolonged timescales. Although the temperatures, pressures and timescales of reaction were very different between the experimental and natural samples, several common reactions and associated processes/reactions were identified:

1) Carbonation did not result in the wholesale disintegration of the borehole cement sample used, or the natural material.

2) Both free-phase $\mathrm{CO}_{2}$ and dissolved $\mathrm{CO}_{2}$ caused significant carbonation of the cement minerals. In the laboratory experiments this resulted in increasing bulk sample density, though it did not alter the overall sample size.

3) Carbonation reactions involved the rapid conversion of portlandite and $\mathrm{CSH}$ phases to $\mathrm{CaCO}_{3}$ (aragonite, calcite and vaterite, which over time became dominated by the more stable polymorph, calcite). This reaction also produced appreciable amounts of silica gel.

4) A well-defined 'reaction front' was observed within the reacted samples, marking the boundary of where CSH phases were stable, and thus where much of the original cement texture still existed.

5) Just in advance of the main reaction front, reaction with $\mathrm{CO}_{2} / \mathrm{HCO}_{3}{ }^{-} / \mathrm{CO}_{3}{ }^{2-}$ had mobilised $\mathrm{Ca}$, creating an enhanced porosity, leached layer.

6) On a microscopic scale there was evidence for large solids volume changes around the 'reaction front'. This appears to have stressed the sample enough to create a zone of microfractures, which may have facilitated $\mathrm{CO}_{2}$ ingress into the sample.

The experimental samples also revealed other details associated with the carbonation process:

1) The outer parts of the samples showed 'relict' reaction fronts, with many fine-scale, nearly concentric bands of $\mathrm{CaCO}_{3}$ and silica gel. The carbonate-rich zones appeared to be of lower porosity and the silica-rich zones appeared to be of higher porosity.

2) The main 'reaction front' appears to have been associated with a large step in porewater $\mathrm{pH}$ - higher $\mathrm{pH}$ being associated with the presence of $\mathrm{CSH}$ phases. This facilitated uptake and enrichment of $\mathrm{Cl}$ by the cement, within a narrow zone ( $2 \mathrm{~mm}$ wide) ahead of the leading edge of the main carbonation front. The $\mathrm{Cl}$ is closely associated with the formation of a $\mathrm{Cl}$-rich $\mathrm{CSH}$ gel and hydrocalumite $\left[\mathrm{Ca}_{4} \mathrm{Al}_{2} \mathrm{O}_{6} \mathrm{Cl}_{2} \cdot 10 \mathrm{H}_{2} \mathrm{O}\right]$. This $\mathrm{Cl}$ uptake observed in the cement was mirrored by significant decreases in dissolved $\mathrm{Cl}^{-}$concentrations in the experimental solutions. 
There was however, one notable difference between the experimental and natural samples related to the carbonation reaction zone. In the experimental samples some carbonation was found in advance of the main reaction front within the apparently 'unaltered' centres of the samples. However, in the natural material this appeared to mark the maximum ingress of $\mathrm{CO}_{2} / \mathrm{HCO}_{3}{ }^{-} / \mathrm{CO}_{3}{ }^{2-}$. The carbonated outer zone was also much thinner in the natural samples. It is unclear as to why the experimental samples are more 'transmissive' compared to the natural samples, but it is noted that:

1) The amounts of $\mathrm{CO}_{2} / \mathrm{HCO}_{3}{ }^{-} / \mathrm{CO}_{3}{ }^{2-}$ available to the two systems were very different. The high $\mathrm{CO}_{2}$ partial pressure in the experimental system would have resulted in a high chemical gradient. This may have effectively enhanced the rate of $\mathrm{CO}_{2}$ migration to a point where it exceeded the uptake ability of the carbonation reactions at the reaction front.

2) The experiments were very short compared to the timescales of natural carbonation, and carbonation was much more rapid in the experiments. This very rapid carbonation favoured the precipitation of a complex mixed assemblage of microporous $\mathrm{CaCO}_{3}$ polymorphs, which included metastable vaterite and aragonite, as well as the more stable calcite. It is quite feasible that in the long-term the recrystallisation of metastable vaterite and aragonite to the more stable calcite might act to reduce the permeability of the initially-formed carbonated outer layer of the samples, and hence reduce the rate of carbonation. In the case of the natural analogue $\mathrm{CSH}$ minerals, a slower carbonation rate may have produced a more coherent calcite-dominated reaction rim, which would reduce diffusion of atmospheric $\mathrm{CO}_{2}$ or $\mathrm{HCO}_{3}{ }^{-}$in groundwater and may also explain why the carbonated zone of the natural samples was thinner.

This study has highlighted some of the complexities of cement mineral carbonation reactions, and has identified phases that might usefully be included in improved geochemical models of $\mathrm{CO}_{2}$ cement reactions. It has also highlighted natural analogues of cement carbonation as a possible source of useful information on long-term cement carbonation processes. Indeed, the presence of CSH minerals apparently protected for thousands of years by a carbonate 'rind' lends some support to the idea that carbonation of the borehole cement matrix could be of limited extent, and possibly even that limited carbonation may act to protect the remaining cement from further reaction. However, the behaviour of cement/steel and cement/rock interfaces during carbonation will be crucial in assessing overall well performance. Continued study of experimental, natural analogue and recovered samples of old well cements are needed to increase confidence in understanding of the engineered seals of a $\mathrm{CO}_{2}$ storage site.

\section{Acknowledgements}

This work was undertaken as part of $\mathrm{CO}_{2} \mathrm{GeoNet}$, a European Commission (EC) funded Network of Excellence. The EC is gratefully acknowledged for its co-funding of this work (under EC Project SES6-CT-2004-502816). Statoil are thanked for providing a sample of borehole steel and background data, and BJ Services are thanks for providing the components to make up the borehole cement. BGS colleagues D. Wagner and A. Lacinska are thanked for their help with the mineralogical analyses. The authors gratefully acknowledge the late W.I. Mitchell (BGS, Northern Ireland) for his support and help with field sampling at Scawt Hill and Carneal Plug. The authors also thank the other participants of the CO2GeoNet project 'JRAP-14' for useful discussions during the project: S. Durucan, E. Lécolier, N. Jacquemet and Ji-Q, Shi. Bill Carey and an anonymous reviewer are thanked for their comments that helped improve this paper. This paper is published with the permission of the Executive Director of the British Geological Survey, NERC.

\section{References}


Alexander, W.R. (Ed.), 1992. A natural analogue study of the Maqarin hyperalkaline groundwaters. I: Source term description and thermodynamic testing. Nagra Technical Report, 91-10.

Bachu, S., Bennion, D.B., 2009. Experimental assessment of brine and/or $\mathrm{CO}_{2}$ leakage through well cements at reservoir conditions. Internat. J. Greenhouse Gas Control 3, 494-501.

Burton, E.A. Walter, L.M., 1987. Relative precipitation rates of aragonite and Mg calcite from seawater: temperature or carbonate ion control? Geology 15, 111-114

Carey, J. W., Svec, R., Grigg, R., Zhang, J., Crow, W., 2010. Experimental investi- gation of wellbore integrity and $\mathrm{CO}_{2}$-brine flow along the casing-cement microannulus. Internat. J. Greenhouse Gas Control 4, 272-282.

Carey, J. W., Wigand, M., Chipera, S., WoldeGabriel, G., Pawar, R., Lichtner, P., Wehner, S., Raines, M., Guthrie, G. D., Jr., 2007. Analysis and performance of oil well cement with 30 years of $\mathrm{CO}_{2}$ exposure from the SACROC Unit, West Texas, USA. Internat. J. Greenhouse Gas Control 1, 75-85.

Crow, W., Carey, J. W., Gasda, S., Williams, D. B., Celia, M., 2010. Wellbore integrity analysis of a natural CO2 producer. Internat. J. Greenhouse Gas Control 4, 186-197.

Dai, J., Song, Y., Dai, C., Wang, D., 1996. Geochemistry and accumulation of carbon dioxide gases in China. Am. Assoc. Petrol. Geolog. Bull. 80, 1615-1626.

Emeleus, C.H., Preston, J., Francis, E.H., 1969. Field Excursion Guide: The Tertiary Volcanic Rocks of Ireland. Queens University, Belfast.

Gaus, I., Azaroual, M., Czernichowski-lauriol, I., 2005. Reactive transport modelling of the impact of $\mathrm{CO}_{2}$ injection on the clayey cap rock at Sleipner (North Sea). Chem. Geol. 217, 319-337.

Geological Survey of Northern Ireland, 2001. Ballymena. Northern Ireland Sheet 20 (Solid and Drift Edition) 1:50,000 Series. British Geological Survey, Keyworth, Nottingham.

Gherardi, F., Xu, T., Pruess, K., 2007. Numerical modelling of self-limiting and self-enhancing caprock alteration induced by $\mathrm{CO}_{2}$ storage in a depleted gas reservoir. Chem. Geol. 244, 103129.

Griffith, A.E., Wilson, H.E., 1982. Geology of the country around Carrickfergus and Bangor. Memoir for One-Inch Geological Sheet 29, $2^{\text {nd }}$ ed. Geological Survey of Northern Ireland, Institute of Geological Sciences, Belfast, HMSO.

Hewlett, P.C. (Ed.), 1998. Lea's Chemistry of Cement and Concrete, $4^{\text {th }}$ ed), Elsevier, Amsterdam.

IEA 2005. Report on well bore integrity workshop. Organised by IEA Greenhouse Gas R\&D Programme and BP with the support of ERI. 4-5 April 2005, Houston, Texas, USA.

IPCC, 2005. IPCC Special Report on Carbon Dioxide Capture and Storage. Prepared by Working Group III of the Intergovernmental Panel on Climate Change, Metz, B., Davidson, O., de Coninck, H.C., Loos, M., Meyer, L.A. (Eds). Cambridge University Press, Cambridge, UK and New York.

Jacquemet, N., Pironon, J., Caroli, E. 2005. A new experimental procedure for simulation of $\mathrm{H}_{2} \mathrm{~S}+$ $\mathrm{CO}_{2}$ geological storage, application to well cement aging. Oil Gas Sci. Technol. - Rev. IFP 60, 193-206.

Knauss, K.G., Johnson, J.W., Steefel, C.I., 2005. Evaluation of the impact of $\mathrm{CO}_{2}$, co-contaminant gas, aqueous fluid and reservoir rock interactions on the geologic sequestration of $\mathrm{CO}_{2}$. Chem. Geol. 217, 339-350.

Kutchko, B., Strazisar, B., Dzombak, D., Lowry, G., Thaulow, N., 2007. Degradation of well cement by $\mathrm{CO}_{2}$ under geologic sequestration conditions. Environ. Sci. Technol. 41, 4787-4792.

Kutchko, B., Strazisar, B., Dzombak, D., Lowry, G., Thaulow, N., 2008. Rate of $\mathrm{CO}_{2}$ attack on Class H well cement under geologic sequestration conditions. Environ. Sci. Technol. 42, 62376242.

LeNeveu, D.M., 2008. CQUESTRA, a risk and performance assessment code for geological sequestration of carbon dioxide. Energy Conversion Manage. 49, 32-46. 
McConnell, J.D.C., 1960. Vaterite from Ballycraigy, Larne, Northern Ireland. Mineral. Mag. 32, 535-545.

Milodowski, A.E., Gillespie, M.R., Naden, J., Fortey, N.J., Sheperd, T.J., Pearce, J.M., Metcalfe, R., 1998. The petrology and paragenesis of fracture mineralization in the Sellafield area, west Cumbria. Proceedings of the Yorkshire Geological Society, 52, 215-241.

Milodowski, A.E., Nancarrow, P.H.A., Spiro, B., 1989. A mineralogical and stable isotope study of natural analogues of Ordinary Portland Cement (OPC) and $\mathrm{CaO}-\mathrm{SiO}_{2}-\mathrm{H}_{2} \mathrm{O}(\mathrm{CSH})$ compounds. United Kingdom Nirex Safety Studies Report, NSS/R240.

Milodowski, A.E., Wagner, D., Lacinska, A., 2009. A natural analogue study of $\mathrm{CO}_{2}$-cement interaction: carbonate alteration of calcium silicate hydrate-bearing rocks from Northern Ireland. British Geological Survey Commissioned Report, CR/09/096.

Mitchell, W.I., 2004. The Geology of Northern Ireland. Geological Survey of Northern Ireland, Belfast.

Pearce, J.M., Holloway, S., Wacker, H., Nelis, M.K., Rochelle, C.A., Bateman, K., 1996. Natural occurrences as analogues for the geological disposal of carbon dioxide. Energy Conversion Manage. 37, 1123-1128.

Petzet, G.A., 1997. Arizona's Holbrook $\mathrm{CO}_{2}$ area may hold oil, gas reserves. Oil Gas J. 95, 84-85.

Rochelle, C.A., Bateman, K., Milodowski, A.E., Kemp, S.J., Birchall, D., 2006. Geochemical interactions between $\mathrm{CO}_{2}$ and seals above the Utsira Formation: An experimental study. British Geological Survey Commissioned Report, CR/06/069.

Rochelle, C.A., Milodowski, A.E., Lacinska, A., Richardson, C., Shaw, R., Taylor, H., Wagner D., Bateman K., 2009. An experimental investigation of the geochemical interactions between $\mathrm{CO}_{2}$ and borehole materials. British Geological Survey Report, OR/09/039.

Rochelle, C.A, Milodowski, A.E., Shi J-Q., Munoz-Mendez, G., Jacquemet, N., Lecolier, E., 2007. A review of the potential impact of $\mathrm{CO}_{2}$ on the integrity of well infrastructure for underground $\mathrm{CO}_{2}$ storage. British Geological Survey Commissioned Report, CR/07/204.

Sabine, P.A., 1975. Metamorphic processes at high temperatures and low pressure: the Petrogenesis of the metasomatized and assimilated rocks of Carneal Plug, Co. Antrim. Phil.Trans. Roy. Soc. London 280(A), 225-265.

Sabine, P.A., Beckinsale, R.D., Evans, J.D., Walsh, J.N., 1982. Geochemical and strontium isotope studies of reactions between basic magma, Chalk, and flint, and the role of groundwater, in the Carneal Plug, Co. Antrim, Northern Ireland. J. Petrol. 23, 427-446.

Sabine, P.A., Styles, M.T., Young, B.R., 1985. The nature and paragenesis of natural bredigite and associated minerals fro Carneal and Scawt Hill, Co. Antrim. Mineral. Mag. 49, 663-670.

Snyder, R.L., Bish, D.L., 1989. Quantitative analysis. In: Bish, D.L., Post, J.E. (Eds), Modern Powder Diffraction. Reviews in Mineralogy 20, 101-144 (Chapter 5).

Spanos, N., Koutsoukos, P.G., 1998. The transformation of vaterite to calcite: effect of the conditions of the solutions in contact with the mineral phase. J. Crystal Growth 191, 783-790.

Tilley, C.E., 1929. On larnite (calcium orthosilicate, a new mineral) and its associated minerals from the limestone contact-zone of Scawt Hill, Co. Antrim. Mineral. Mag. 22, 77-86.

Tilley, C.E., 1930. Scawtite, a new mineral from Scawt Hill, Co. Antrim. Mineral. Mag. 22, 222224.

Tilley, C.E., 1933. Portlandite, a new mineral from Scawt Hill, Co. Antrim. Mineral. Mag. 23, 419420.

Tilley, C.E., Alderman, A.R., 1934. Progressive metamorphism in the flint nodules of the Scawt Hill contact-zone. Mineral. Mag. 23, 513-518.

Tilley, C.E., Harwood, H.F., 1931. The dolerite-chalk contact of Scawt Hill, Co. Antrim. The production of basic alkali-rocks by the assimilation of limestone by basaltic magma. Mineral. Mag. 22, 439-468. 
Tilley, C.E., Vincent, H.C.G., 1948. The occurrence of an orthorhombic high-temperature form of $\mathrm{Ca}_{2} \mathrm{SiO}_{4}$ (bredigite) in the Scawt Hill contact-zone and as a constituent of slags. Mineral. Mag.28, 255-271.

Wigand, M., Kaszuba, J.P., Carey, J.W., Hollis, W.K., 2009. Geochemical effects of $\mathrm{CO}_{2}$ sequestration on fractured wellbore cement at the cement/caprock interface. Chem. Geol. 265, 122-133.

Xu, T., Apps, J.A., Pruess, K., 2005. Mineral sequestration of carbon dioxide in a sandstone-shale system. Chem. Geol. 217, 295-318.

Zerai, B., Saylor, B.Z., Matisoff, G., 2006. Computer simulation of $\mathrm{CO}_{2}$ trapped through mineral precipitation in the Rose Run Sandstone, Ohio. Appl. Geochem. 21, 223-240.

Zhang, M., Bachu, S., 2011. Review of integrity of existing wells in relation to $\mathrm{CO}_{2}$ geologic storage: What do we know? Internat. J. Greenhouse Gas Control 5, 826-840.

Zhang, X., Wen, Z., Gu, Z., Xu, X., Lin, Z., 2004. Hydrothermal synthesis and thermodynamic analysis of dawsonite-type compounds.Journal of Solid State Chemistry, 177, 849-855.

Zhou, G-T., Yao, Q-Z., Fu, S-Q., Guan, Y-B., 2010. Controlled crystallization of unstable vaterite with distinct morphologies and their polymorphic transition to stable calcite. Eur. J. Min. 22, 259-269. 


\section{Captions}

Figure 1. Schematic diagram showing the typical layout inside a simple batch reactor. The $\mathrm{CO}_{2}$ (or $\mathrm{N}_{2}$ ) acted as both a pressurising medium and reactant.

Figure 2a. Sideways view of a freshly-exposed fracture surface through a reacted cement-steel composite block. The cement (left hand side) displays a thick pale buff reaction zone (A) around a residual core of light grey cement $(\mathrm{C})$, both separated by a visible reaction front $(\mathrm{B})$. The surface of the steel exposed from the cement-steel interface is pitted and coated with a red-brown Fe oxyhydroxide alteration product.

Figure 2b. Polished vertical section through a reacted steel-cement composite sample (steel-cement contact on left of image) showing a carbonated reaction rim (A) with concentric banding (reaction and 'shrinkage' fronts) around a relict core of partially reacted cement $(\mathrm{C})$. Blue dye resin picks out a network of open microfractures produced by shrinkage of the cement. Cavities, lined or partially filled by blue-dye-stained bentonite, are evident along the steel-cement interface (D). These cavities were possibly formed during depressurisation and degassing. Areas where sample preparation has 'plucked' material from this part of the section are white.

Figure 3a. SEM photomicrograph (BSE imaging mode) from saline water- $\mathrm{CO}_{2}$ experiment (Run 1232) showing reaction products consisting of rosettes of $\mathrm{CaCO}_{3}$ crystals (probably largely calcite or aragonite) coating the upper surface of the reacted steel-cement composite along the cement-steel interface close to the exposed steel surface. Siderite (white) can be seen as an interstitial phase between the crystalline $\mathrm{CaCO}_{3}$ coating.

Figure 3b. BSEM photomicrograph of section through outer edge of carbonated cement plug. The cement close to the outer edge has been strongly leached of Ca with enhanced microporosity and formation of secondary amorphous silica.

Figure 4. BSEM image and corresponding EDXA distribution maps for $\mathrm{Ca}, \mathrm{Si}$ and $\mathrm{Cl}$ recorded from the interface between the outer carbonated reaction zone and the inner 'relict cement' core zone, observed in polished block of reaction products from Run 1232. Note the increased concentration of $\mathrm{Cl}$ on the inner side of the interface between the two zones.

Figure 5. Simplified map showing the location of the Scawt Hill and Carneal dolerite plugs, Northern Ireland, UK with photograph of the SE face of Scawt Hill (top) and simplified sketch of the main geological features of the exposed dolerite plug and the adjacent country rocks (bottom).

Figure 6a. Very hydrous gel-like phase formed by hydration and alteration of a calcsilicate (larnite) nodule, which was revealed in a freshly broken open block of marble from Scawt Hill.

Figure 6b. Highly metasomatised and partially assimilated hornfelsed xenolith of Ulster White Limestone Formation rock, containing metamorphosed chert concretions at Carneal Plug. The rock is irregularly veined by dark hybrid pyroxenite.

Figure 6c. Section through an altered larnite-spurrite-scawtite nodule (sample MPLM796) from Scawt Hill showing concentrically banded alteration around a residual core of the original calcsilicate metamorphic rock

Figure 6d. Transmitted light photomicrograph of thin section through altered calcsilicate nodule from Scawt Hill. It shows zoned alteration: A - quartz-rich zone with minor larnite; B - larnite with minor spurrite or paraspurrite; $\mathrm{C}$ - inner zone of the late-stage alteration rim, with secondary porosity highlighted by blue resin; D - zone of carbonation reaction with scawtite, amorphous silica and $\mathrm{CaCO}_{3}$; E - host marble.

Figure 7a. Transmitted light photomicrograph (plane polarised light) showing detail of the shrinkage of CSH gel (clear) associated with its alteration and replacement by microgranular $\mathrm{CaCO}_{3}$ and silica. Opaque grain is secondary goethite after primary magnetite. Porosity revealed by blue dye impregnation.

Figure $7 \mathbf{b}$. Transmitted photomicrograph of a sample from Carneal Plug showing diffuse microporosity (shown by the blue dye resin imparting a pale blue body colour to the CSH 
matrix) developed with altered and carbonated Ca silicate hydrate. Partially carbonated areas of the CSH (replaced by microgranular Ca carbonates) are only weakly impregnated or are unimpregnated by the blue dye resin. Shrinkage of the CSH during drying has accentuated the opening of a fracture (filled with blue epoxy resin) along the margins of a cross-fibre calcite vein (white) cutting through the partially carbonated CSH.

Figure 8. Mechanistic sketch of carbonation reaction mechanisms.

Table 1. Quantities of components needed to make $600 \mathrm{~mL}$ of borehole cement slurry (as supplied by BJ Services).

Table 2. Quantities of chemicals used to make $8 \mathrm{~L}$ of synthetic Utsira porewater (SUP batch $2=$ 'SUP2'). A 1 L aliquot of this fluid was spiked with $\mathrm{D}$ and ${ }^{18} \mathrm{O}$ isotopes and used in the composite block experiments (identifier = 'SUP2 isotope'), though analysis for isotopes is not reported here.

Table 3. Details of laboratory experiments and the changes in weight of cement. The experiments ran for 110 days at $30^{\circ} \mathrm{C}$ and 80 bar and used composite blocks of borehole cement and steel.

Table 4. Summary of XRD mineralogy data for initial cement and reacted cement from the experiments (excluding amorphous phases, and normalised to 100\%).

Table 5. Results of fluid chemical analyses.

Table 6. Comparison of the mineralogy of hydrated OPC paste and naturally-hydrated larnite nodules from Scawt Hill and Carneal Plug (excluding carbonation products, anhydrous Portland cement clinker phases, and natural primary metamorphic minerals in the nodules). 